一技術報告一

ミトコンドリア DNA 検査のマルチプレックス化および高速化に関する研究

三田裕介，北山哲史，深川貴志，綿引晴彦，

藤井宏治, 中原弘明，水野なつ子，関口和正

\author{
科学警察研究所 \\ 干277-0882 千葉県柏市柏の葉 6-3-1
}

\title{
Study of multiplex PCR and high-speed PCR of mitochondrial DNA analysis
}

\author{
Yusuke Mita, Tetsushi Kitayama, Takashi Fukagawa, Haruhiko Watahiki, Koji Fujii, \\ Hiroaki Nakahara, Natsuko Mizuno and Kazumasa Sekiguchi \\ National Research Institute of Police Science \\ 6-3-1, Kashiwanoha, Kashiwa, Chiba 277-0882, Japan
}

(Received 31 August 2017; accepted 21 May 2018;

Published online 9 July 2018 in J-STAGE DOI: 10.3408/jafst.742)

\begin{abstract}
Mitochondrial DNA (mtDNA) analysis is a useful tool to analyze forensic samples. MtDNA exists as numerous molecules in a single cell in contrast to nuclear DNA, therefore mtDNA analysis can provide successful results in analyzing minute DNA samples. In our current PCR protocol of mtDNA analysis, hypervariable region 1 (HV1) and hypervariable region 2 (HV2) are divided into 5 regions (region A to $\mathrm{E}$ ), and each region is amplified separately. It requires labor and long PCR time. In this paper, we study multiplex PCR of mtDNA and high-speed PCR using high-speed DNA polymerase to reduce labor and time of mtDNA analysis.
\end{abstract}

Key words: Mitochondrial DNA, mtDNA, Multiplex PCR, High-speed PCR

\author{
緒 言 \\ ミトコンドリア DNA 検査は細胞内小器官である \\ ミトコンドリアが持つDNAの塩基配列を解析する \\ 手法であり，法科学分野に拈いて広く用いられてい \\ る手法である1)。ミトコンドリアDNA は母系遺伝 \\ であり母系親族間では同じ配列を持つため，ミトコ \\ ンドリアDNA 検査は，核 DNAを用いた STR 型 \\ 検査に比べて識別力が制限される。しかし核 DNA \\ とは異なり，ミトコンドリア DNA は一細胞あたり
}

に多くのコピーが存在する2)ため, STR 型が得られ ない自然脱落毛や白骨，歯牙などのサンプルにおい ても，ミトコンドリア DNA 配列が得られる場合も あり有用である。 また塩基配列解析による異同識別 では, 現場資料と対照資料から得られた塩基配列が 一致するか否かを調べるが，ミトコンドリア DNA は母系親族間では同一配列となるため, 本人資料が 得られない場合でも，対照資料を母系親族から採取 することが可能である．このため母系親族の確認に も用いられ, 白骨死体等の身元確認のためにも利用 
されている. 科学警察研究所では, 平成 8 年より刑 事事件や変死事案における法科学資料に対してミト コンドリア DNA 検査を行っており，陳旧化が進ん だ資料の検査や母系親族の確認をする場合におい て，ミトコンドリアDNA 検査を活用してきた。 ま た日本人 1366 人のミトコンドリア DNA 配列の集団 データを報告3-4)している.

現在, 科学警察研究所で実際の検査に用いられて いる現行手法5)では, hypervariable region 1 (HV1, 16040-16375) と hypervariable region 2 (HV2, 64339）の領域を， $\mathrm{A} \sim \mathrm{E}$ の 5 つの領域に分けて PCR を行っている (Fig. 1). 通常の検査では HV1 領域 に対応する A 領域, および HV2 領域に対応する D 領域の塩基配列の解析を行う. 一方で, HV1 領域 および HV2 領域には, シトシン $(\mathrm{C})$ が連続して 存在し, その下流の配列が読めなくなる C-stretch ${ }^{6,7)}$ が知られている. C-stretch が存在する 々塩基配列分析を双方向で行えなくなるため, HV1 にC-stretch が存在した場合は B およびC 領 域を，HV2 に C-stretch が存在した場合は E 領域を
追加で検査することによって, 各領域の塩基配列を 双方向で分析し，塩基配列を決定している. 現行手 法では一つのサンプルを解析するにあたって, 多く のPCR を必要とし，またその PCRに必要な時間 も長い。また, 現在では改良された試薬が多数市販 されている一方で, 古い試薬は販売中止になるリス クを含んでいるため，ミトコンドリア DNA 検査を 安定的に維持するためには, ミトコンドリアDNA 検査手法の研究開発を継続的に行っていく必要性が ある、そこで本論文では，ミトコンドリアDNA 検 査に抢ける PCR の簡便化・迅速化を目指すにあた って，PCRのマルチプレックス化を検討し，また 新試薬を用いた PCR 時間の短縮についても検討し たので報告する.

\section{材料および方法 \\ 1. 用いたサンプル \\ 実験に用いたサンプルは, 成人男性 5 名に由来す る, 血痕（約 10 ヶ月間室温保存）・ 口腔内細胞（使 用日当日に採取) - 自然脱落毛毛幹部 (採取加ら数}
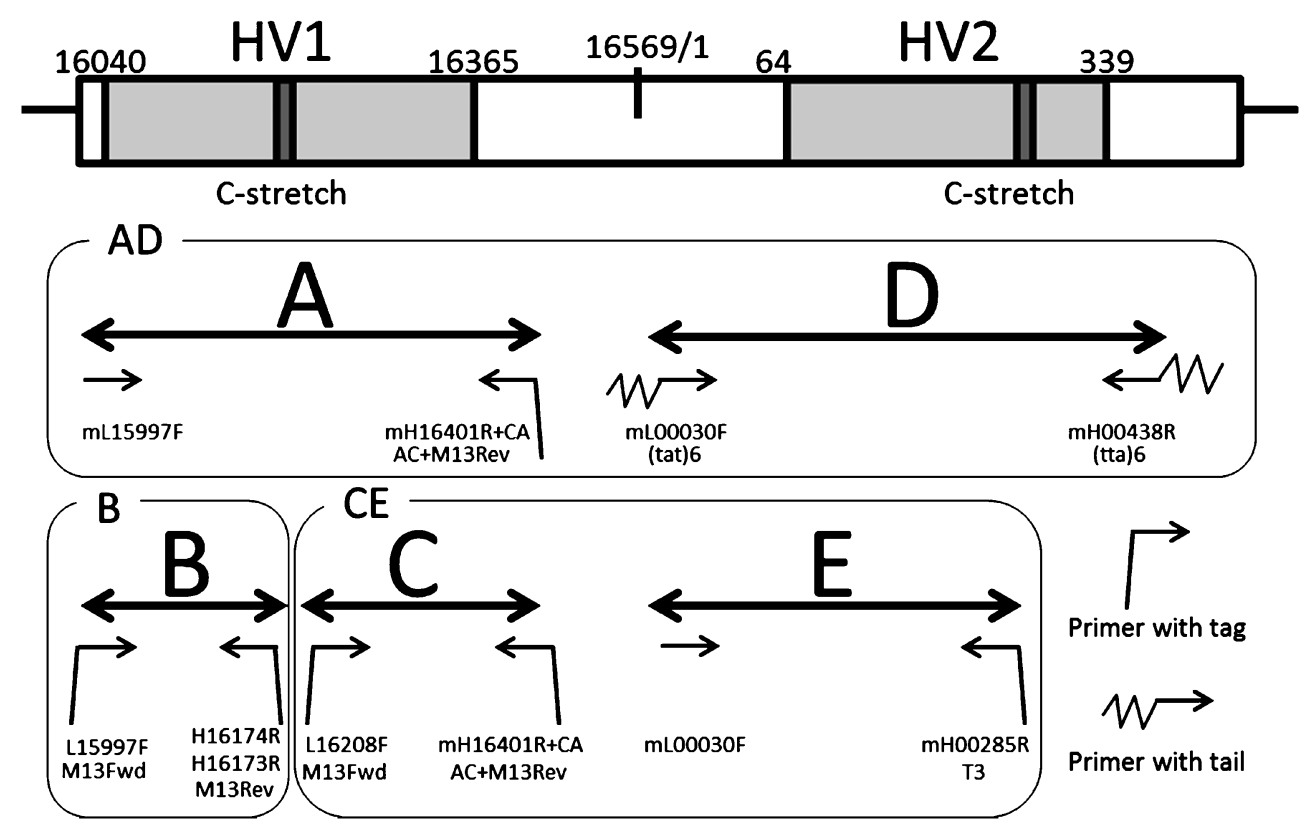

Fig. 1 Design of region A to E and multiplex PCR.

Light grey color boxes represent HV1 region (16040-16365) and HV2 region (64-339) of mitochondria DNA. Dark grey color boxes represent C-stretch. Two-way arrows represent region A to E. See table 3. for sequences of primers. Multiplex PCR are designed as region AD to amplify region $\mathrm{A}$ and $\mathrm{D}$, and region $\mathrm{CE}$ to amplify region C and E. Singleplex PCR is applied to region B. 
日間室温保存）をそれぞれ用いた。DNAの抽出は EZ1 DNA Investigator kit（キアゲン)，あるいは QIAamp DNA Investigator Kit で行った. DNAの 抽出に当たっては各キットのプロトコールに従っ た。 なたコントロールDNA として2800M control DNA（プロメガ）を用いた。なお本研究は科学警 察研究所倫理審査委員会の承認を得て行った.

\section{2. 定量}

DNA 溶液中のミトコンドリアDNA コピー数の 定量は，Smart Cycler II System（セフィード）を用 いたリアルタイム PCR で定量を行った。プライ マーは論文 ${ }^{8}$ 記載の C 領域 $(231 \mathrm{bp})$ を増幅するプ ライマーからタグ部分を除いた配列である5'CCCCATGCTTACAAG-3'抢よび 5'-TGATTT CACGGAGGATGGTG-3’を用いた。反応系は 25 $\mu \mathrm{L}$ 系とし, 各試薬（カッコ内は最終濃度）として, SYBR $^{\circledR}$ Premix Ex Taq ${ }^{\mathrm{TM}}$ (Tli RNaseH Plus)（タカ ラバイオ $)(\times 1)$ ，プライマー (各 $0.5 \mu \mathrm{M})$ に DNA 溶液 $2 \mu \mathrm{L}$ と水を加えて $25 \mu \mathrm{L}$ とした。 PCR 条件は, $95^{\circ} \mathrm{C} 10$ 秒の熱変性後, $\left(95^{\circ} \mathrm{C} 5\right.$ 秒 $\cdot 60^{\circ} \mathrm{C}$ 20秒）のPCR サイクルを35回に設定し，SYBR Green Iによる検出を行った。ミトコンドリア DNAのコピー数の算出には, 文献8)記載の手法で ミトコンドリアDNAのコピー数を算出した K562
DNA（プロメガ）を用いて検量線を作成し，その 検量線に従ってコピー数を概算した（K562 DNA 1 $\mathrm{ng} / \mu \mathrm{L} \fallingdotseq \mathrm{MtDNA} 1 \times 10^{6}$ copies $\left./ \mu \mathrm{L}\right)$. 核 DNA の定 量は論文 ${ }^{9-10)}$ に従って D17Z1 領域の207 bp を用い た.

\section{PCR}

3-1. AmpliTaq Gold ${ }^{\circledR}$ を用いたシングルプレック 又 (現行手法)

文献5)の手法に従い，抽出 DNA を用いて，ミト コンドリアDNAの HV1 領域およびHV2 領域を PCR 増幅した. 用いたプライマーは Table 1 に示 した。 サーマルサイクラーは GeneAmp ${ }^{\circledR}$ PCR System 9700 （アプライドバイオシステムズ）を用い, ランプスピードは9600エミュレーションモードで運 転した。なおアニーリング時のランプレートを文献 5）記載の50\%から60\%に変更している（Table 2). これはランプレートを $1{ }^{\circ} \mathrm{C} /$ 秒に設定するため, サーマルサイクラーごとにバリデーションを行った 結果に基づくものである.

3-2. AmpliTaq Gold ${ }^{\circledR}$ を用いたマルチプレックス 抽出 DNA を, $\mathrm{AD}$ 領域, $\mathrm{B}$ 領域, $\mathrm{CE}$ 領域の 3 つの反応に分けてマルチプレックス PCR（B 領域 のみシングルプレックス PCR）を行った. 反応系 は $25 \mu \mathrm{L}$ 系とし，各試薬（カッコ内は最終濃度）と

Table 1 Singleplex PCR primers.

\begin{tabular}{|c|c|c|c|c|c|c|}
\hline & position & name & Sequence $^{\mathrm{a})}$ & tag/tail & $\begin{array}{c}\mathrm{Tm} \\
\left.\left({ }^{\circ} \mathrm{C}\right) \mathrm{b}\right)\end{array}$ & Descripstion \\
\hline \multirow[t]{2}{*}{ A } & $\mathrm{AF}$ & L15997F & tgtaaaacgacggccagtCACCATTAGCACCCAAAGCT & M13Fwd & 58.45 & \\
\hline & AR & H16401R & caggaaacagctatgaccTGATTTCACGGAGGATGGTG & M13Rev & 57.60 & \\
\hline \multirow[t]{2}{*}{$\mathrm{D}$} & DF & L00029F & tgtaaaacgacggccagtGGTCTATCACCCTATTAACCAC & M13Fwd & 55.41 & \\
\hline & DR & H00438R & caggaaacagctatgaccGGGAAAATAATGTGTTAGTTG & M13Rev & 50.75 & \\
\hline \multirow[t]{3}{*}{ B } & $\mathrm{BF}$ & L15997F & tgtaaaacgacggccagtCACCATTAGCACCCAAAGCT & M13Fwd & 58.45 & $\begin{array}{l}\text { This primer was the same } \\
\text { as AF primer. }\end{array}$ \\
\hline & $\mathrm{BR}$ & H16174R & caggaaacagctatgaccGGGGGTTTTGATGTG & M13Rev & 47.73 & \\
\hline & & H16173R & caggaaacagctatgaccGGGGGGGTTTGATGTGG & M13Rev & 57.03 & $\begin{array}{l}\text { This primer was added for } \\
\text { PCR of C-strech samples. }\end{array}$ \\
\hline \multirow[t]{2}{*}{$\mathrm{C}$} & $\mathrm{CF}$ & L16208F & tgtaaaacgacggccagtCCCCATGCTTACAAGCAAG & M13Fwd & 56.57 & \\
\hline & $\mathrm{CR}$ & $\mathrm{H} 16401 \mathrm{R}$ & caggaaacagctatgaccTGATTTCACGGAGGATGGTG & M13Rev & 57.60 & $\begin{array}{l}\text { This primer was the same } \\
\text { as AR primer. }\end{array}$ \\
\hline \multirow[t]{2}{*}{$\mathrm{E}$} & $\mathrm{EF}$ & L00029F & tgtaaaacgacggccagtGGTCTATCACCCTATTAACCAC & M13Fwd & 55.41 & $\begin{array}{l}\text { This primer was the same } \\
\text { as DF primer. }\end{array}$ \\
\hline & ER & H00290R & caggaaacagctatgaccGGGGGGGTTTGGTGGAAATT & M13Rev & 60.47 & \\
\hline
\end{tabular}

a) Small letters ( $\mathrm{a}, \mathrm{t}, \mathrm{g}$ and $\mathrm{c}$ ) were tag or tail sequences.

b) Tm was caluculated with Primer-BLAST. These Tm of primers were caluculated as original primers without tags or tails. 
Table 2 PCR condition.

\begin{tabular}{|c|c|c|c|c|c|c|c|c|c|}
\hline & Enzyme & $\begin{array}{c}\text { single/ } \\
\text { multi }\end{array}$ & Activation & Denaturation & Annealing & Elongation & $\begin{array}{l}\text { Ramp } \\
\text { speed }\end{array}$ & Cycles & $\begin{array}{l}\text { Total } \\
\text { time }\end{array}$ \\
\hline $\begin{array}{l}\text { Our conventional } \\
\text { method }\end{array}$ & AmpliTaq Gold ${ }^{\circledR}$ & single & $\begin{array}{l}95^{\circ} \mathrm{C} \\
9 \mathrm{~min}\end{array}$ & $\begin{array}{l}95^{\circ} \mathrm{C} \\
45 \mathrm{sec}\end{array}$ & $\begin{array}{c}60^{\circ} \mathrm{C}\left(60 \% \%^{\mathrm{a})}\right) \\
1 \mathrm{~min}\end{array}$ & $\begin{array}{l}72^{\circ} \mathrm{C} \\
2 \mathrm{~min}\end{array}$ & $\begin{array}{l}9600 \\
\text { emulation }\end{array}$ & & $\begin{array}{c}2 \mathrm{~h} \\
45 \mathrm{~min}\end{array}$ \\
\hline $\begin{array}{l}\text { Multiplex with } \\
\text { Taq Gold }\end{array}$ & AmpliTaq Gold $^{\circledR}$ & multi & $\begin{array}{l}95^{\circ} \mathrm{C} \\
9 \mathrm{~min}\end{array}$ & $\begin{array}{l}95^{\circ} \mathrm{C} \\
45^{\mathrm{sec}}\end{array}$ & $\begin{array}{c}60^{\circ} \mathrm{C}\left(60 \% \%^{\mathrm{a})}\right), \\
1 \mathrm{~min}\end{array}$ & $\begin{array}{l}72^{\circ} \mathrm{C} \\
2 \mathrm{~min}\end{array}$ & $\begin{array}{l}9600 \\
\text { emulation }\end{array}$ & 33 times & $\begin{array}{c}2 \mathrm{~h} \\
45 \mathrm{~min}\end{array}$ \\
\hline $\begin{array}{l}\text { High speed } \\
\text { single plex }\end{array}$ & $\begin{array}{l}\text { TaKaRa Taq }{ }^{\mathrm{TM}} \\
\text { Fast Detect }\end{array}$ & single & - & $\begin{array}{l}94^{\circ} \mathrm{C} \\
5 \mathrm{sec}\end{array}$ & $\begin{array}{c}60^{\circ} \mathrm{C}\left(60 \% \%^{\mathrm{a})}\right), \\
1 \mathrm{sec}\end{array}$ & $\begin{array}{l}68^{\circ} \mathrm{C} \\
10 \mathrm{sec}\end{array}$ & $\max$ & 33 times & $45 \mathrm{~min}$ \\
\hline $\begin{array}{l}\text { High speed } \\
\text { single plex }\end{array}$ & $\begin{array}{l}\text { AmpliTaq Gold } \\
\text { Fast Master Mix }\end{array}$ & single & $\begin{array}{l}95^{\circ} \mathrm{C} \\
10 \mathrm{~min}\end{array}$ & $\begin{array}{l}96^{\circ} \mathrm{C} \\
3 \mathrm{sec}\end{array}$ & $\begin{array}{c}60^{\circ} \mathrm{C}\left(60 \% \%^{\mathrm{a})}\right), \\
3 \mathrm{sec}\end{array}$ & $\begin{array}{l}68^{\circ} \mathrm{C} \\
10 \mathrm{sec}\end{array}$ & $\max$ & 33 times & $60 \mathrm{~min}$ \\
\hline
\end{tabular}

a) Ramp rate between denaturation and annealing was $60 \%$.

Table 3 Multiplex PCR primers.

\begin{tabular}{|c|c|c|c|c|c|c|}
\hline & Position & name & Sequence $\left.^{a}\right)$ & Tag/tail & $\underset{\left({ }^{\circ} \mathrm{C}\right)^{\mathrm{b})}}{\mathrm{Tm}}$ & Descripstion \\
\hline \multirow[t]{4}{*}{$\mathrm{AD}$} & $\mathrm{AF}$ & mL15997F & CACCATTAGCACCCAAAGCT & - & 58.45 & \\
\hline & AR & $\mathrm{mH} 16401 \mathrm{R}+\mathrm{CA}$ & accaggaaacagctatgaccTGATTTCACGGAGGATGGTG & $\mathrm{AC}+\mathrm{M} 13 \mathrm{Rev}$ & 57.6 & \\
\hline & DF & $\mathrm{mL} 00030 \mathrm{~F}$ & tattattattattattatGGTCTATCACCCTATTAACCACT & (tat) 6 & 56.85 & \\
\hline & DR & $\mathrm{mH} 00438 \mathrm{R}$ & ttattattattattattaGGGAAAATAATGTGTTAGTTG & (tta) 6 & 50.75 & \\
\hline \multirow[t]{3}{*}{$\mathrm{B}$} & $\mathrm{BF}$ & $\mathrm{L} 15997 \mathrm{~F}$ & tgtaaaacgacggccagtCACCATTAGCACCCAAAGCT & M13Fwd & 58.45 & \\
\hline & BR & H16174R & caggaaacagctatgaccGGGGGTTTTGATGTG & M13Rev & 47.33 & \\
\hline & & H16173R & caggaaacagctatgaccGGGGGGGTTTGATGTGG & M13Rev & 57.03 & $\begin{array}{l}\text { This primer was added for } \\
\text { PCR of C-strech samples. }\end{array}$ \\
\hline \multirow[t]{4}{*}{$\mathrm{CE}$} & $\mathrm{CF}$ & L16208F & tgtaaaacgacggccagtCCCCATGCTTACAAGCAAG & M13Fwd & 56.57 & $\begin{array}{l}\text { This primer was the same } \\
\text { as CF primer in Table } 2 \text {. }\end{array}$ \\
\hline & $\mathrm{CR}$ & $\mathrm{mH} 16401 \mathrm{R}+\mathrm{CA}$ & accaggaaacagctatgaccTGATTTCACGGAGGATGGTG & $\mathrm{AC}+\mathrm{M} 13 \mathrm{Rev}$ & 57.6 & $\begin{array}{l}\text { This primer was the same } \\
\text { as AR primer. }\end{array}$ \\
\hline & $\mathrm{EF}$ & $\mathrm{mL} 00030 \mathrm{~F}$ & tattattattattattatGGTCTATCACCCTATTAACCACT & (tat) 6 & 56.85 & $\begin{array}{l}\text { This primer was the same } \\
\text { as DF primer. }\end{array}$ \\
\hline & ER & $\mathrm{mH} 00285 \mathrm{R}$ & attaaccetcactaaagggaaGGGGTTTGGTGGAAATTTTTTG & $\mathrm{T} 3$ & 57.09 & $\begin{array}{l}\text { Int. J. Leg. Med., 1995, } \\
\text { 108, } 68\end{array}$ \\
\hline
\end{tabular}

a) Small letters (a, t, g and c) were tag or tail sequences.

b) Tm was caluculated with Primer-BLAST. These Tm of primers were caluculated as original primers without tags or tails.

して, dNTP $(200 \mu \mathrm{M})$ （サーモフィッシャーサイ エンティフィック), GeneAmp ${ }^{\circledR} 10 \times$ PCR Gold Buffer (×1) (サーモフィッシャーサイエンティフ イック), AmpliTaq Gold ${ }^{\circledast}(0.05$ unit $/ \mu \mathrm{L})$ （サーモ

フィッシャーサイエンティフィック), $\mathrm{MgCl}_{2}$ (2.5 $\mathrm{mM}$ ）（サーモフィッシャーサイエンティフィッ ク), $\operatorname{BSA}(0.2 \mu \mathrm{g} / \mu \mathrm{L})$ (シグマアルドリッチ), 各 プライマー $($ 各 $0.5 \mu \mathrm{M})$ （ユーロフィンジェノミク ス）を加え，これに抽出 DNA（ミトコンドリア DNA コピー数 $10^{3} \sim 5 \times 10^{4}$ copies/reaction）と水を 加えて $25 \mu \mathrm{L}$ に調製を行い，PCR 反応を行った. 用いたプライマーは Table 3 に示した. PCR 条件 は, $95^{\circ} \mathrm{C} 9$ 分の熱変性後, $\left(95^{\circ} \mathrm{C} 45\right.$ 秒 $\cdot 60^{\circ} \mathrm{C}(60 \%)$ 30 秒 $\cdot 72^{\circ} \mathrm{C} 2$ 分）の PCR サイクルを33回に設定し た（Table 2)。なお，サーマルサイクラーは
GeneAmp ${ }^{\circledR}$ PCR System 9700を用いて，ランプス ピードは9600エミュレーションモードで運転を行 い，アニーリング時のランプレートは $60 \%$ とした。

3-3. 高速 PCR 試薬を用いたシングルプレックス 高速 PCR 試薬として, TaKaRa Taq ${ }^{\mathrm{TM}}$ HS Fast Detect (タカラバイオ), および AmpliTaq Gold ${ }^{\circledR}$ Fast Master Mix（サーモフィッシャーサイエンティ フィック）を用いた PCR を行った，反応系はそれ ぞれ $20 \mu \mathrm{L}$ とし，各試薬（カッコ内は最終濃度）と して, TaKaRa Taq HS Fast Detect Premix $(\times 1)$, もしくは AmpliTaq Gold ${ }^{\circledR}$ Fast PCR Master Mix, $\mathrm{UP}(\times 1)$ に対して, 各プライマー (各0.625 $\mu \mathrm{M})$ (ユーロフィンジェノミクス), 抽出 DNA（ミトコ ンドリアコピー数 $10^{3} \sim 5 \times 10^{4}$ copies/reaction） と 水を加えて $20 \mu \mathrm{L}$ に調製を行い， PCR 反応を行っ 
た. プライマーは 3-1 と同様のものを用いた.

TaKaRa $\mathrm{Taq}^{\mathrm{TM}}$ HS Fast Detect $の$ PCR 条件は, $\left(94^{\circ} \mathrm{C} 5\right.$ 秒 $\cdot 60^{\circ} \mathrm{C}(60 \%) 1$ 秒 $\cdot 68^{\circ} \mathrm{C} 10$ 秒) $9 \mathrm{PCR}$ サイクルを33回に設定した（Table 2)。なお，サー マルサイクラーは GeneAmp ${ }^{\circledR}$ PCR System 9700を 用いて，ランプスピードは Max モードで運転を行 い，アニーリング時のランプレートは $60 \%$ とした (Table 2).

また, AmpliTaq Gold ${ }^{\circledR}$ Fast Master Mix $の$ PCR 条件は, $95^{\circ} \mathrm{C} 10$ 分の熱变性後 $\left(96^{\circ} \mathrm{C} 3\right.$ 秒 $\cdot 60^{\circ} \mathrm{C}$ (60\%) 3 秒 $\cdot 68^{\circ} \mathrm{C} 10$ 秒）の PCR サイクルを 33 回 に設定した。な扮，サーマルサイクラーは GeneAmp ${ }^{\circledR}$ PCR System 9700を用いて, ランプス ピードは Max モードで運転を行い，アニーリング 時のランプレートは60\%とした（Table 2).

\section{PCR 産物確認}

シーケンス反応を行う前の PCR 産物増幅確認と して，アガロースゲル電気泳動を行った．SeaKem $\mathrm{GTG}^{\mathrm{TM}}$ アガロース（ロソザ）をSYBR ${ }^{\circledR}$ Safe DNA Gel Stain in $1 \times$ TAE（サーモフィッシャーサイエン ティフィック）に溶解してアガロース濃度は $2 \%(\mathrm{w}$ /w）とし，TAEバッファー中で， $100 \mathrm{~V}$ あるは
$120 \mathrm{~V}$ で10分間泳動を行った.

\section{5. マルチプレックス PCR 産物解析}

マルチプレックス PCR 産物の解析には Agilent DNA 1000キット（アジレント・テクノロジー）を 用い，2100バイオアナライザ（アジレント・テク） ロジー）で解析した．試料の調製はマニュアルに従 い, PCR 産物 $1 \mu \mathrm{L}$ を解析に用いた.

\section{6. シーケンス反応と電気泳動}

PCR 産物の精製には，現行手法では QuickStep $^{\mathrm{TM}} 2$ PCR Purification kit (エッジバイオ システムズ）を用いて，マニュアルに従って精製 PCR 産物を得た。 また，高速 PCR 試薬を用いた PCR 産物の精製には，ExoSAP-IT ${ }^{\circledR （ ア フ ィ メ ト リ ~}$ クス）を用いて，マニュアルに従って精製 PCR 産 物を得た。Taq Gold を用いたマルチプレックス PCR で得たPCR 産物は, 両方の精製法で精製 $\mathrm{PCR}$ 産物を得た。シーケンス反応には BigDye ${ }^{\circledR}$ Terminator v1.1 Cycle Sequencing Kit（サーモフィ ッシャーサイエンティフィック）を用いた. 1 反応 あたり, Ready Reaction Premix $2 \mu \mathrm{L}$, BigDye Sequencing Buffer $3 \mu \mathrm{L}$, 精製 PCR 産物 1-2 $\mu \mathrm{L}$, 各 シーケンスプライマー（Table 4)（最終濃度 0.16

Table 4 Sequence primers.

\begin{tabular}{|c|c|c|c|c|c|c|}
\hline $\begin{array}{l}\text { single/ } \\
\text { multi }\end{array}$ & \multicolumn{2}{|c|}{ position } & name & Sequence $^{\text {a) }}$ & $\underset{\left.\left({ }^{\circ} \mathrm{C}\right)^{\mathrm{b}}\right)}{\mathrm{Tm}}$ & Descripstion \\
\hline \multirow[t]{2}{*}{ singleplex } & \multirow{2}{*}{\multicolumn{2}{|c|}{$\begin{array}{l}\text { forward } \\
\text { reverse }\end{array}$}} & M13FWD & tgtaaaacgacggccagt & 56.82 & M13 forward primer \\
\hline & & & M13REV & caggaaacagctatgacc & 52.34 & M13 reverse primer \\
\hline \multirow[t]{10}{*}{ multiplex } & \multirow[t]{4}{*}{$\mathrm{AD}$} & $\mathrm{AF}$ & mL15997F & CACCATTAGCACCCAAAGCT & 58.45 & $\begin{array}{l}\text { This primer was the same } \\
\text { as PCR primer }\end{array}$ \\
\hline & & AR & M13REV & caggaaacagctatgacc & 52.34 & M13 reverse primer \\
\hline & & $\mathrm{DF}$ & sL00029F & GGTCTATCACCCTATTAACCAC & 55.41 & \\
\hline & & DR & sH00438R & GGGAAAATAATGTGTTAGTTG & 50.75 & \\
\hline & \multirow[t]{2}{*}{ B } & $\mathrm{BF}$ & M13FWD & tgtaaaacgacggccagt & 56.82 & M13 forward primer \\
\hline & & $\mathrm{BR}$ & M13REV & caggaaacagctatgacc & 52.34 & M13 reverse primer \\
\hline & \multirow[t]{4}{*}{$\mathrm{CE}$} & $\mathrm{CF}$ & M13FWD & tgtaaaacgacggccagt & 56.82 & M13 forward primer \\
\hline & & $\mathrm{CR}$ & M13REV & caggaaacagctatgacc & 52.34 & M13 reverse primer \\
\hline & & $\mathrm{EF}$ & sL00029F & GGTCTATCACCCTATTAACCAC & 55.41 & $\begin{array}{l}\text { This primer was the same } \\
\text { as DF sequence primer }\end{array}$ \\
\hline & & ER & T3_seq_primer & attaacctcactaaagggaa & 53.82 & $\mathrm{~T} 3$ primer \\
\hline
\end{tabular}

a) Capital letters (A, T, G and C) were sequences of original mitochondria DNA and small letters (a, t, $g$ and c) were sequences of sequencing tags.

b) Tm was caluculated with Primer-BLAST. These Tm of primers were caluculated as original primers without tags or tails. 
$\mu \mathrm{M})$ に水を加えて $20 \mu \mathrm{L}$ とし， $\left(95^{\circ} \mathrm{C} 15\right.$ 秒 $\cdot 50^{\circ} \mathrm{C}$ (60\%) 5 秒・ $60^{\circ} \mathrm{C} 2$ 分）を 25 サイクルでシーケン ス反応を行った。得られたシーケンス産物を Gel Filtaration Cartridge（エッジバイオシステムズ） を用いて，マニュアルに従って精製を行い，得られ た精製産物を濃縮乾燥した。濃縮乾燥後, Hi-Di ${ }^{\mathrm{TM}}$ Formamide（サーモフィッシャーサイエンティフ イック） $10 \mu \mathrm{L}$ に溶解し, 電気泳動サンプルとし た. 電気泳動は3130xl Genetic Analyzer（アプライ ドバイオシステムズ）を用いて, 泳動条件は $36 \mathrm{~cm}$ キャピラリー，3130 POP-4TM, UltraSeq36_POP4 で 行った。データの解析は Sequencing Analysis Software 6 (v6.0)（アプライドバイオシステムズ） および，SEQUNCHER ${ }^{\mathrm{TM}} 5.0$ (ジーンコード）を 用いて解析した.

\section{結果}

1. マルチプレックス PCR の設計と結果

ミトコンドリア DNA 検査の簡便化を目指して, マルチプレックス PCR 系の構築と検討を行った. 現行手法に打ける $5 つ$ の $\mathrm{A}$ E 領域のうち, $\mathrm{BCE}$ 領域を 1 反応にまとめたマルチプレックス PCR 系 を検討したが，予備検討の段階で B 領域の増幅効 率が極端に悪かった（data not shown）ため, マル チプレックス PCR 系では, $\mathrm{AD}$ 領域, $\mathrm{B}$ 領域, $\mathrm{CE}$ 領域の 3 反応に分けてそれぞれ PCR を行うように 設計した（Fig. 1). プライマー配列を Table 3 に示 L, 以下本条件で行う PCR をマルチプレックス法 と表記する。なお Table 3 中に示した Tm の值は, 各プライマーにおいて，タグ配列（シーケンス用プ ライマー結合部位）あるいはテイル配列（PCR 産 物長調整のために付加された配列）を除いた部分の 配列に対して, Primer-BLAST ${ }^{11)}$ を用いて計算を行 った。プライマーの設計に当たっては, 現行の科警 研で使用しているプライマー（Table 1) を基本に， 一部の配列を変更したものを設計した．な抢設計に 当たっては, PCR 産物長の調節を目的として 3 塩 基の繰り返し配列12)を付加し，また CE 領域におい ては, マルチプレックス時における各領域の PCR 増幅のバランスを改善するため, ER プライマーを 近傍領域の文献既知のプライマー13) に変更した。



Fig. 2 Analysis of multiplex PCR with AmpliTaq Gold by Agilent 2100 .

Lanes of $\mathrm{AD}, \mathrm{B}$, and $\mathrm{CE}$ represent analysis of PCR products of region AD (multiplex), region $\mathrm{B}$ (sigleplex), and region CE (multiplex), respectively. Lanes of NAD, NB, NCE represent analysis of each negative controls.

設計したマルチプレックス法を実施し，PCR 産 物を Agilent DNA 1000キットで解析した結果を示 す (Fig. 2). AD 領域では, 二本のバンドが観察さ れ, PCR 産物長から, 短いバンドを $\mathrm{A}$ 領域の PCR 産物（463 bp)，長いバンドを D 領域の PCR 産物 （487 bp）と帰属した。B 領域では B 領域の PCR 産物長（246 bp）に相当するシングルバンドが得ら れた. CE 領域では二本のバンドが検出され，短い バンドを C 領域の PCR 産物 $(268 \mathrm{bp})$, 長いバン ドを $\mathrm{E}$ 領域の PCR 産物（338 bp）と帰属した。マ ルチプレックス PCR で増幅した PCR 産物からで も各シーケンスプライマーにより，ノイズのない単 独のシーケンスが得られた。シーケンスを行った成 人男性 5 名の血痕, 口腔内細胞, 自然脱落毛毛髪毛 幹部の計15サンプルにおいては，マルチプレックス 法にて得られた HV1 領域および HV2 領域の配列 と, 現行法で得られた HV1 領域および HV2 領域 の配列は，C-stretch 領域の C の数を除きすべて一 致した。

2. 高速 PCR 試薬を用いたシングルプレックスの 検討と結果

2-1. TaKaRa Taq ${ }^{\mathrm{TM}}$ HS Fast Detect の検討

TaKaRa Taq ${ }^{\mathrm{TM}}$ HS Fast Detect, および現行法の プライマー（Table 1) を用いて PCR 増幅を行った 




Fig. 3 A representative electropherogram of region A of blood stain DNA amplified by TaKaRa Taq ${ }^{\mathrm{TM}}$ HS Fast Detect.

Major peaks were target sequence of region A of mitochondrial DNA. Minor peaks were detected when region A of blood stain DNA was amplified by TaKaRa Taq ${ }^{\mathrm{TM}}$ HS Fast Detect.

ところ，PCR 反応時間は現行法の 2 時間 45 分か ら，45分に短縮された（Table 2)。口腔内細胞由来 DNA および自然脱落毛毛幹部由来 DNA からは， $\mathrm{A} \sim \mathrm{E}$ 領域のいずれの領域の PCR 増幅産物から良 好なシーケンス結果を得た (data not shown)。一 方で血痕由来 DNA では, A 領域以外の PCR 増幅 産物では良好なシーケンスが得られたものの， A 領域増幅時において目的とする配列に加えて，目的 配列以外の配列がバックグラウンドノイズとして検 出された（Fig. 3).

\section{2-2. AmpliTaq Gold ${ }^{\circledR}$ Fast Master Mix $の$ 検討}

AmpliTaq Gold ${ }^{\circledR}$ Fast Master Mix，および現行法 のプライマー（Table 1）を用いて PCR 増幅を行っ たところ，PCR 反応時間は現行法の 2 時間 45 分か ら，60分に短縮された (Table 2). PCR 産物増幅 確認の結果を Fig. 4 に示す。血痕由来 DNA，口腔 内細胞由来 DNA，自然脱落毛由来 DNA のいずれ からも，良好なシーケンス結果を得た（Fig. 5). シーケンスを行った成人男性 5 名の血痕, 口腔内細 胞, 自然脱落毛毛幹部の計15サンプルにおいては, 得られた HV1 領域および HV2 領域の配列と, 現 行法で得られた HV1 領域および HV2 領域の配列 は，C-stretch 領域の C の数を除きすべて一致し た。

\section{PCR の簡便化と迅速化}

ミトコンドリア DNA 検査の簡便化のために，マ ルチプレックス法の開発を行った。 その結果, マル チプレックス法では $\mathrm{AD}$ 領域，および $\mathrm{CE}$ 領域の



Fig. 4 PCR amplification of singleplex with AmpliTaq Gold ${ }^{\circledR}$ Fast Master Mix.

Lane A to E represent amplicon of region $\mathrm{A}$ to $\mathrm{E}$ amplified with AmpliTaq Gold ${ }^{\circledR}$ Fast Master Mix. Lane NC means negative control.

PCR をマルチプレックス化することに成功し, 工 程数の削減を達成した。 また，ミトコンドリア DNA 検査のさらなる迅速化を目指し, 高速 PCR 試薬を用いた PCR 時間の短縮化を検討した結果, 大幅に PCR 所要時間を短縮させた（Table 2)。さ らにプレミックス化された高速 PCR 試薬を使用す ることによって, 試薬調製の簡便化が図れるためコ ンタミリスクの低減が期待される。 なお C-stretch 領域におけるシトシン (C) の数は, 個人内でも変 動があることが知られており7)，今回の評価におい て，C-stretch 領域の C の数が一致しなかったもの に関しては，個人内変動に由来するものと考察して いる。また，高速 PCR 試薬を用いたマルチプレッ クス法の開発も検討したが， $\mathrm{AD}$ 領域のマルチプレ ックスPCRに拈いて，AmpliTaq Gold ${ }^{\circledR}$ を用いた マルチプレックス PCR と比較して D 領域の増幅効 率が悪く，感度の低下が認められた（data not shown). 



Fig. 5 A representative electropherogram of region A of blood stain DNA amplified by AmpliTaq Gold ${ }^{\circledR}$ Fast Master Mix.

\section{TaKaRa Taq ${ }^{\mathrm{TM}}$ HS Fast Detect における非特異} 増幅産物について

常染色体上には，ミトコンドリアDNAの偽遺伝 子が存在して抢り，それらはNUMTs (Nuclear mitochondrial pseudogenes) として知られてい る14-16). TaKaRa Taq ${ }^{\mathrm{TM}}$ HS Fast Detectを用いた PCR では，血液由来 DNA を鋳型にした時のみ， 目的となるミトコンドリア配列以外に非特異増幅産 物が確認された。 またPCRに用いたプライマーと 非特異増幅産物の解析から, ヒト17番染色体上にフ ォワードプライマーおよびリバースプライマーに対 して 1 塩基ずつミスマッチが存在する領域が確認さ れ, また非特異増幅産物由来のマイナーピークとし て推定される配列がその領域内に存在していた (22520807 to 22521251 of Homo sapiens chromosome 17, GRCh38.p7 Primary Assembly (NCBI Reference Sequence: NC_000017.11); data not shown). さらにこの領域は17番染色体上に存在す るNUMTとして文献報告された領域14) と, 同一の 塩基配列を有する。このことから TaKaRa Taq ${ }^{\mathrm{TM}}$ HS Fast Detect で観察された非特異増幅産物はヒト 常染色体上の配列に由来する可能性がある.

\section{3. 検查手法の評価}

本論文では, 新規のミトコンドリア DNA 検査手 法として，AmpliTaq Gold ${ }^{\circledR}$ を用いたマルチプレッ クス PCR，および高速 PCR 試薬を用いたシングル プレックス PCR 法の報告を行った. いずれの手法 についても使用可能であると考えているが，PCR の非特異増幅産物の有無, コンタミネーションリス クの低さ, 試薬の継続性, 作業の簡便性などを考慮 すると，AmpliTaq Gold ${ }^{\circledR}$ Fast Master Mix を用いた
高速 PCR 法が，総合的に最も優れていると著者ら は考えている.

\section{結 語}

著者らはミトコンドリア DNA 検査の簡便化・迅 速化を図るため，マルチプレックス化の検討を行 い, 従来 $\mathrm{A} \sim \mathrm{E}$ の 5 領域をシングルプレックス PCR ていた現行法を基に, AD 領域, $\mathrm{B}$ 領域, $\mathrm{CE}$ 領域の 3 領域からなるマルチプレックス法を構 築した。また高速 PCR に対応したPCR プレミッ クス試薬を用いることで, PCRの簡便化・迅速化 を達成した。これらは PCR に必要な時間を短縮す るだけでなく，作業の簡便化に伴いコンタミネーシ ヨンリスクの低減も期待できると考えられる．今後 は総合的に最も優れていると考えられる AmpliTaq Gold ${ }^{\circledR}$ Fast Master Mix を用いた高速 PCR 法につい て，バリデーション17)を実施する予定であるが, STR に関するバリデーションの報告18-22) がある一 方で, 我々の知る限り, ミトコンドリア DNA 検査 のバリデーション手法の報告はない。ゆえに，ミト コンドリア DNA 検査のバリデーション項目および パラメータの妥当性も含めて, 検証を行い, 法科学 的ミトコンドリア DNA 分析の手法の確立を進めて いきたい。

\section{文 献}

1) Melton T., Holland C., Holland M., Forensic Mitochondrial DNA Analysis: Current Practice and Future Potential, Forensic Sci. Rev., 24, 101122, 2012.

2) Parson W., Gusmao L., Hares D. R., Irwin J. 
A., Mayr W. R., Morling N., Pokorak E., Prinz M., Salas A., Schneider P. M., Parsons T. J., DNA Commission of the International Society for Forensic Genetics: revised and extended guidelines for mitochondrial DNA typing, Forensic Sci. Int. Genet., 13, 134-142, 2014.

3) Sekiguchi K., Imaizumi K., Fujii K., Mizuno N., Ogawa Y., Akutsu T., Nakahara H., Kitayama T., Kasai K., Mitochondrial DNA population data of $\mathrm{HV} 1$ and HV2 sequences from Japanese individuals, Leg. Med. (Tokyo), 10, 284 $-286,2008$.

4) Imaizumi K., Parsons T. J., Yoshino M., Holland M. M., A new database of mitochondrial DNA hypervariable regions I and II sequences from 162 Japanese individuals, Int. J. Legal Med., 116, 68-73, 2002.

5) Sekiguchi K., Imaizumi K., Matsuda H., Mizuno N., Yoshida K., Senju H., Sato H., Kasai K., MtDNA Sequence Analysis Using Capillary Electrophoresis and Its Application to the Analysis of MtDNA in Hair, Jpn. J. Sci. Tech. Iden., 7, 123130, 2003.

6) Bendall K. E., Sykes B. C., Length heteroplasmy in the first hypervariable segment of the human mtDNA control region, Am. J. Hum. Genet., 57, 248-256, 1995.

7) Stewart J. E., Fisher C. L., Aagaard P. J., Wilson M. R., Isenberg A. R., Polanskey D., Pokorak E., DiZinno J. A., Budowle B., Length variation in HV2 of the human mitochondrial DNA control region, J. Forensic Sci., 46, 862870, 2001.

8) Nakahara H., Sekiguchi K., Imaizumi K., Mizuno N., Kasai K., Heteroplasmies detected in an amplified mitochondrial DNA control region from a small amount of template, J. Forensic Sci., 53, 306-311, 2008.

9）中原弘明, 藤井宏治, 水野なつ子, 吉田日南 子，笠井賢太郎，法生物学的試料由来の DNA に対する定量法の検証, 日本法科学技術学会
誌, 12, 13-26, 2007.

10) Kitayama T., Fujii K., Nakahara H., Mizuno N., Kasai K., Yonezawa N., Sekiguchi K., Estimation of the detection rate in STR analysis by determining the DNA degradation ratio using quantitative PCR, Leg. Med. (Tokyo), 15, 1-6, 2013.

11) Ye J., Coulouris G., Zaretskaya I., Cutcutache I., Rozen S., Madden T. L., Primer-BLAST: a tool to design target-specific primers for polymerase chain reaction, BMC Bioinformatics, 13, 134, 2012.

12) Kim N. Y., Lee H. Y., Park S. J., Yang W. I., Shin K. J., Modified midi- and mini-multiplex PCR systems for mitochondrial DNA control region sequence analysis in degraded samples, $J$. Forensic Sci., 58, 738-743, 2013.

13) Wilson M. R., DiZinno J. A., Polanskey D., Replogle J., Budowle B., Validation of mitochondrial DNA sequencing for forensic casework analysis, Int. J. Legal Med., 108, 68-74, 1995.

14） Parr R. L., Maki J., Reguly B., Dakubo G. D., Aguirre A., Wittock R., Robinson K., Jakupciak J. P., Thayer R. E., The pseudo-mitochondrial genome influences mistakes in heteroplasmy interpretation, BMC Genomics, 7, 185, 2006.

15) Tsuji J., Frith M. C., Tomii K., Horton P., Mammalian NUMT insertion is non-random, Nucleic Acids Res., 40, 9073-9088, 2012.

16) Dayama G., Emery S. B., Kidd J. M., Mills R. E., The genomic landscape of polymorphic human nuclear mitochondrial insertions, Nucleic Acids Res., 42, 12640-12649, 2014.

17) SWGDAM Validation Guidelines for DNA Analysis Methods, 2016.

18）藤井宏治, 綿引晴彦, 三田裕介, 北山哲史, 中原弘明, 水野なつ子, 関口和正, GlobalFiler による STR 型検査の法科学的評価, 日本法科学 技術学会誌，21，1-23, 2016.

19）藤井宏治，岩島泰樹，北山哲史，中原弘明， 水野なつ子, 関口和正, PowerPlex Fusion System による STR 型検査の法科学的評価, 日本法 
科学技術学会誌, 20, 15-40, 2015.

20) Martin P., de Simon L. F., Luque G., Farfan M. J., Alonso A., Improving DNA data exchange: validation studies on a single 6 dye STR kit with 24 loci, Forensic Sci. Int. Genet., 13, 6878, 2014.

21) Oostdik K., Lenz K., Nye J., Schelling K., Yet D., Bruski S., Strong J., Buchanan C., Sutton J., Linner J., Frazier N., Young H., Matthies L., Sage A., Hahn J., Wells R., Williams N., Price M., Koehler J., Staples M., Swango K. L., Hill C., Oyerly K., Duke W., Katzilierakis L., Ensen- berger M. G., Bourdeau J. M., Sprecher C. J., Krenke B., Storts D. R., Developmental validation of the PowerPlex $((\mathbf{R}))$ Fusion System for analysis of casework and reference samples: A 24locus multiplex for new database standards, Forensic Sci. Int. Genet., 12, 69-76, 2014.

22）綿引晴彦, 藤井宏治, 深川貴志, 三田裕介, 北山哲史, 中原弘明, 水野なつ子, 関口和正, Yfiler Plus PCR Amplification Kit を用いたYSTR 型検査の法科学的評価, 日本法科学技術学 会誌，23，13-34, 2018. 